\title{
DESIGN AND TECHNOLOGICAL PROPOSALS FOR IMPROVING A SINGLE-PHASE TRANSFORMER WITH LAMINATED MAGNETIC CORE
}

Goal. The purpose of the work is to analyze the features and substantiate the advantages of the spatial radial electromagnetic system of a single-phase transformer with rectangular sections of the rods of a charged magnetic circuit. Methodology. Improvement of single-phase transformers is possible by structural-geometric transformations of active elements. The justification of the advantages of such transformations is achieved by the method of invariant objective functions with dimensionless optimization components and universal relative controlled variables. Results. Replacing the rectangular contours of the variants of a planar magnetic circuit with a hexagonal circuit leads to a decrease in the volume of steel and the loss of three angular zones of changes in the direction of the magnetic flux relative to the texture compared to planar counterparts. The separation of the windings into sections with an arrangement on three rods leads to a decrease in the average length of the coil. Originality. A three-core magnetic core can consist of rod and jugular-angular parallelogram plates of anisotropic and isotropic electrical steel. It is advisable to combine a combination of steels by integral welding of billets with subsequent separation into chevron jugular-rod elements. The method called on has developed mathematical models of the mass, cost, and active power losses of variants of a single-phase electromagnetic system of a transformer with rod and armor planar and spatial radial threecore magnetic cores. Practical significance. It was found that the decrease in the extrema of the mass and cost indicators, as well as the calculated decrease, under the condition that the coefficients of additional losses are identical, the extrema of the losses of the single-phase radial three-rod system of the transformer relative to the planar analogue with a bar stocked magnetic wire from anisotropic steel, respectively 13,0-12,3\%, 15,3-10,1\% and 15,1-18,1\% with copper windings and 10,8-10,2 \%, 12,8-13,7 \% and 12,6-12,3 \% with aluminum windings. The main indicators of traditional single-phase systems with rod and armored magnetic circuits differ insignificantly, which is consistent with early known optimization and calculation data of transformers. References 10 , tables 4, figures 4 .

Key words: single-phase transformer, electromagnetic system options, target functions, a combination of electrical steels, mass, cost, loss.

Розглянута можсливість удосконалення однофазних трансформаторів на основі просторової радіальної електромагнітної системи 3 тристрижневим магнітопроводом. Стрижнневі та яремно-кутові ділянки такого магнітопроводу можуть бути виготовленні з паралелограмних пластин анізотропної $і$ ізотропної сталі та з'єднані інтегральним зварюванням заготівок, ще розділяються на шевронні елементи. На основі методу інваріантних цільових функцій з безрозмірними оптимізаційними складовими й універсальними відносними керованими змінними розроблено математичні моделі маси, вартості $і$ втрат активної потужності планарних $і$ радіальної систем зі стрижневим, броньовим та тристрижневим иихтованими магнітопроводами 3 прямокутними перерізами. Отримані безрозмірні числові значення показників технічного рівня вказаних варіантів, що характеризують переваги радіальної тристрижневої електромагнітної системи. Бібл. 10, табл. 4, рис. 4.

Ключові слова: однофазний трансформатор, варіанти електромагнітної системи, цільові функції, комбінація електротехнічних сталей, маса, вартість, втрати.

Рассмотрена возможность усовериенствования однофазных трансформаторов на основе пространственной радиальной электромагнитной системы с трехстержневым магнитопроводом. Стержсневые и яремно-угловые участки такого магнитопровода могут быть выполнены из параллелограмных пластин анизотропной и изотропной стали и соединены интегральной сваркой в разделяемых на шевронные элементы заготовках. На основе метода инвариантных целевых функций с безразмерными оптимизационными составляющими и универсальными относительными управляемыми переменными разработаны математические модели массы, стоимости и потерь активной мощности планарных и радиальной систем с стержневым, броневым и трехстержневым шихтованными магнитопроводами с прямоугольными сечениями. Получены безразмерные числовые значения показателей технического уровня указанных вариантов характеризующие преимущества радиальной трехстержсневой электромагнитной системы. Библ. 10, табл. 4, рис. 4.

Ключевые слова: однофазный трансформатор, варианты электромагнитной системы, целевые функции, комбинация электротехнических сталей, масса, стоимость, потери.

Introduction. In the period from 1970 to 2000 , the losses of transformers were reduced to $50 \%$ [1]. Further increases in energy costs are constantly driving the reduction of losses. With almost incomplete loading of transformers during the service life, reducing no-load losses becomes a priority. It is also important to reduce the weight and cost of each new development of the transformer [1-8]. The main losses of electricity occur in distribution networks with transformers with power of up to $1000 \mathrm{kV} \cdot \mathrm{A}$, among which a significant part are singlephase transformers. Such transformers are produced mainly with rectangular sections of rod and armored planar magnetic cores. The powers of transformers with rectangular cross-sections of rods of laminated magnetic circuits have been increasing recently [8]. The structures of single-phase and three-phase planar electromagnetic systems (EMS) have remained unchanged for a century, which is associated with technological conservatism and the rejection of costs for new developments [2, 3, 7]. In connection with the known shortcomings and the practical limit of the development of traditional designs [2-6], as well as in connection with the need for further energy saving, the tasks of finding and justifying the advantages

(C) A.A. Stavinskiy, A.M. Tsyganov 
of new technical solutions for EMS of transformers are important and relevant.

In the majority of modern works systematized in [7], the main methods and directions for improving transformers, as in the past decades, are the use of new electrical materials. Cardinal methods of energy saving in transformer construction are based on complex technologies for the production of composite conductors of windings with "high-temperature" superconductivity and amorphous electrical steel (ES). However, the cost increases significantly, and questions arise about the specifics of the design, operation and assembly of transformer and technological equipment. Such issues and disadvantages include: the exit of the winding from superconductivity after a protective shutdown, a decrease in the magnetic flux density of the nominal mode and saturation, technological sensitivity to mechanical influences and the fragility of a multilayer amorphous tape. New insulating materials for traditional conductors and cooling systems ("cable" and "SF6" transformers) are being created, and the characteristics of anisotropic and isotropic ES are improved.

There is also known a method for improving transformers by transforming the structures and configurations of EMS elements using both traditional and new materials and existing technological capabilities and equipment [2-6].

The problematic issue of transformer construction is the increase in losses of the finished magnetic core relative to the specific losses of ES [1, 4-7]. In twisted magnetic cores, regardless of the texture, the losses increase due to the iregular distribution of the magnetic field in the cross section with different lengths and saturation of the elementary layers of ES. In laminated magnetic cores made of anisotropic ES, regardless of the shape of the joint, a sharp increase in losses in the angular zones of rotation of the magnetic flux relative to the direction of the texture occures.

The goal of the work is the substantiation of the advantages of the spatial radial EMS of a single-phase transformer with a three-rod laminated magnetic core over traditional planar versions with rectangular crosssections of the rods.

According to [4-6], reduction of losses is possible on the basis of a combination of brands of different ES in sections or elements of magnetic cores.

Reducing the losses of the corner zones of planar laminated magnetic cores with rectangular winding windows is achieved by a combination and alternation of anisotropic and isotropic ES in the rods and yokes [5]. In this case, the transition of the flow from the rod to the yoke occurs in the isotropic ES, but the losses in the rod and yoke sections from the isotropic ES increase relative to similar anisotropic sections.

A significant reduction in no-load losses is possible by performing all corner sections of the combined magnetic core from isotropic ES and all rod and yoke sections from anisotropic ES. However, such a solution in the variants of the EMS planar topology with rod (Fig. 1) and armored (Fig. 2) magnetic cores doubles the number of joints and increases the additional losses and reactive power losses. The task of overlapping joints and ensuring the structural integrity of the magnetic core becomes more complicated.
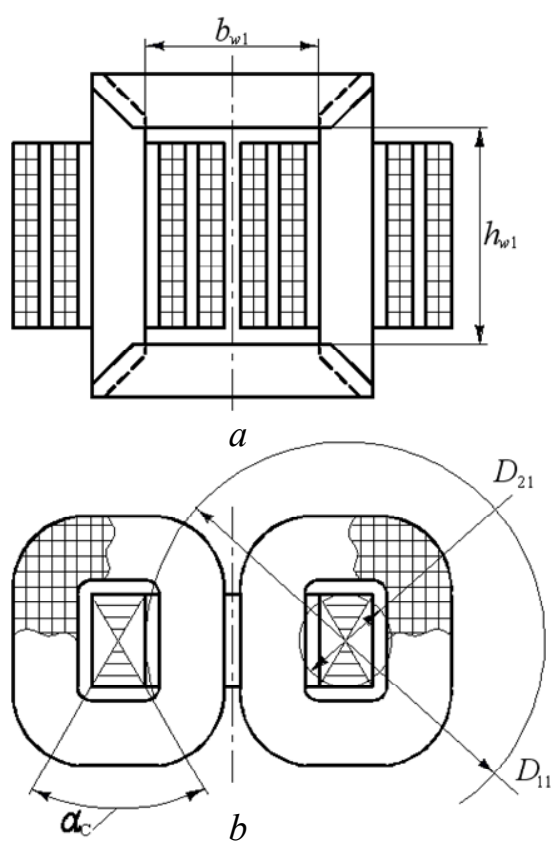

Fig. 1. Single-phase planar electromagnetic system with bar magnetic core in the longitudinal $(a)$ and cross-sections $(b)$

Replacing the rectangular outer contour of the EMS magnetic core (Fig. 1,a) with the contour of a symmetric hexagon creates a spatial radial EMS with minimum volume of the corner zones of the three-rod magnetic core [2] (Fig. 3). The rectangular sections of the winding coils in the windows of the traditional magnetic core are converted into almost triangular sections (Fig. 3,a). In this case, an increase in the winding sections to three leads to a slight decrease in the average length of a turn of the EMS windings (Fig. 3) relative to the analogs (Fig. 1, 2).

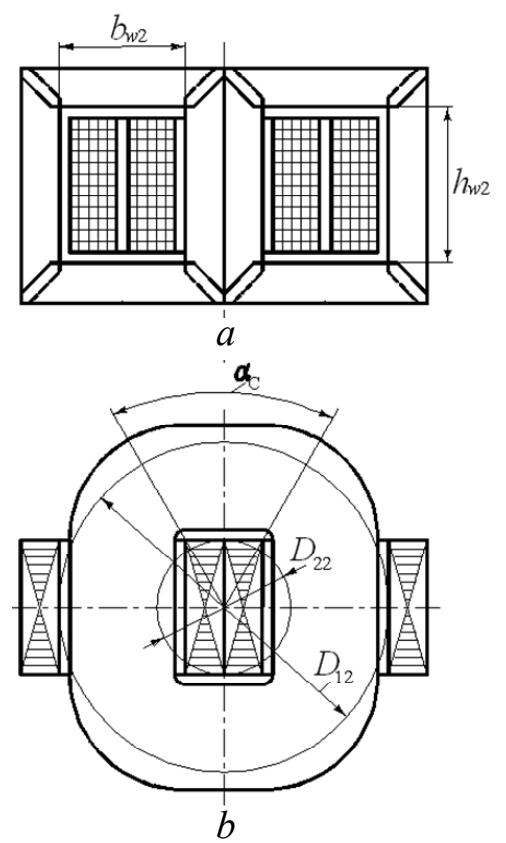

Fig. 2. Single-phase planar electromagnetic system with armored magnetic core in the longitudinal $(a)$ and cross-sections $(b)$ 
These features create the prerequisites for improving single-phase EMS. The rhombic configuration of the joke-angular region creates the minimum mass of the flow turning zones relative to the texture direction. When minimizing the outer EMS contour (Fig. 3), the inner contour can be hexagonal with small central corners of the smaller edges. The connection of the rod and yokeangular sections, respectively, of anisotropic and isotropic ES forms a magnetic core of chevron elements with a reduction in joints from six to three. Laminating of such elements "interlaced" (Fig. 3,a) leads to rotation of adjacent oblique joints by $180^{\circ}$ and solidity of the magnetic circuit. It becomes expedient to solve the problem of permanently joining anisotropic and isotropic sections of chevron plates in joints using a special welding method. Such a joint should reduce current and no-load losses and allow separation of the ES strip.

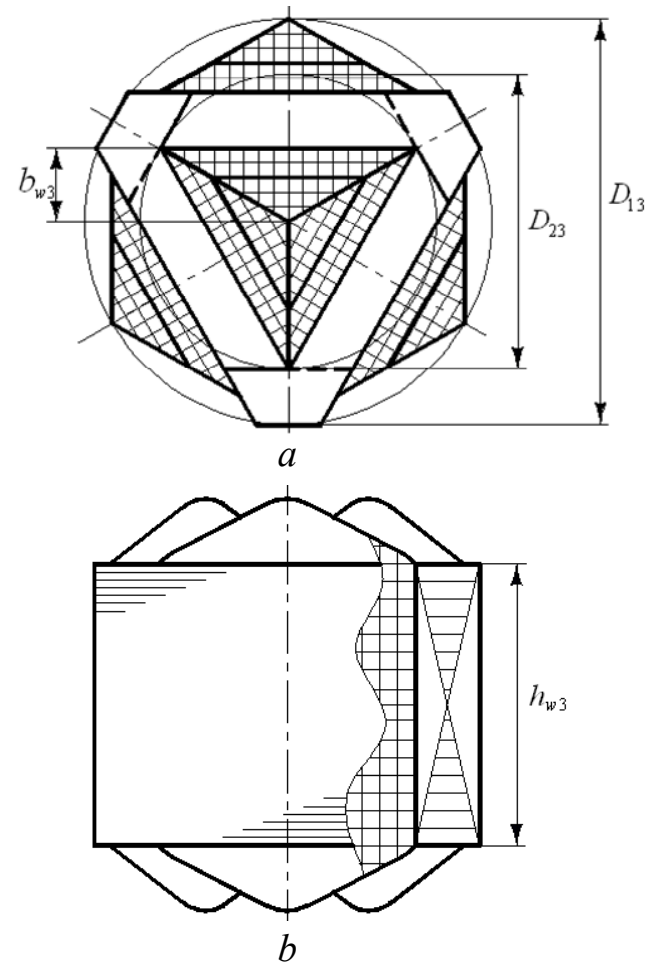

Fig. 3. Single-phase spatial electromagnetic system with threerod magnetic core in a cross-section $(a)$ and with fragment of a longitudinal section $(b)$

Elimination of significant complications in the production of magnetic cores with the connection of joints of isotropic and anisotropic ES is possible by integral welding and transverse separation of workpieces. Workpieces of the ES combination for transverse separation into composite plates of the EMS magnetic core (Fig. 3) are formed by combining and joining along the joint lines of fragments of strips of anisotropic (Fig. $4, a$ ) and isotropic (Fig. 4,b) ES. One, two or more fragments of an isotropic ES strip can be welded to a fragment (fragments) of an anisotropic ETS strip. Before joining the fragments, the anisotropic components are located with the texture direction parallel to the separation lines (Fig. 4,c). The separated sections of fragments with two or several seams are divided at specified angles into plates (Fig. 4,d) with a combination of ES.
Assessment of the effect of structural EMS transformations on the characteristics of the transformer should be carried out by the method of invariant structural synthesis.

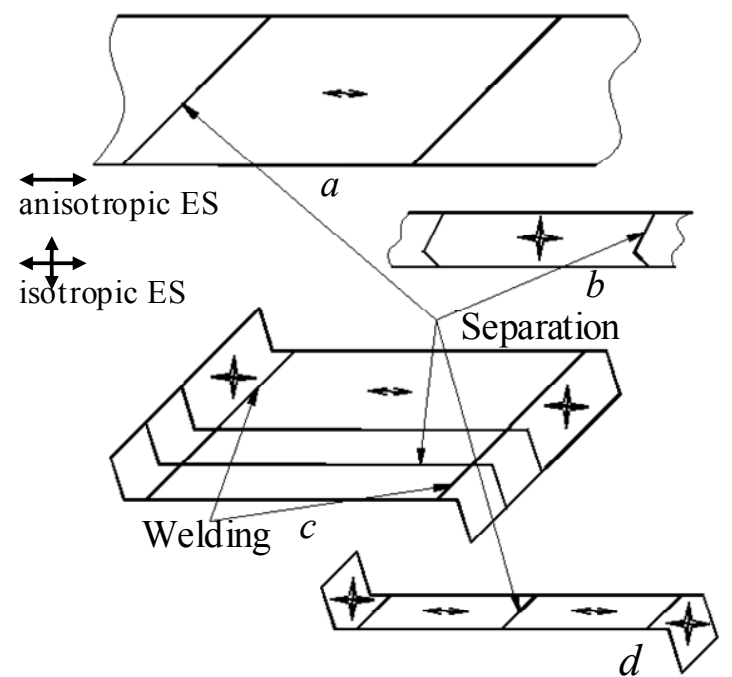

Fig. 4. Components of the combined magnetic core: transverse separation of rolled anisotropic ES $(a)$ and isotropic ES $(b)$ of electrical steels on fragments; welding of fragments along the lines of joints into a workpiece and its transverse division into sections (c); division of sections of fragments into combined plates $(d)$

The well-known optimization mathematical models of transformers, in particular $[1,9,10]$, contain geometrical controlled variables (CV) of EMS elements (diameter of the rod forming contour, aspect ratio of the rectangular cross-section of the rod) and electromagnetic loads (EML). Such models allow performing parametric optimization of transformers of specific powers, structural designs, cooling systems and purposes based on specified criteria. The use of such models complicates the structural synthesis of EMS.

Comparison of EMS options (Fig. 1-3) is carried out by a universal method of structural-parametric synthesis [3, 8]. For a generalized comparison by the named method of any $i$-th options, in this work the rod $(i=1)$, armor $(i=2)$ and radial $(i=3)$ EMS, $i j$ of objective functions with indicators (components) $I^{*}{ }_{i j}$ of the form [3] in dimensionless (relative) units are used:

$$
F_{i j c u(a l)}=\left(I_{T}\right)^{3 / 4} K_{j} I_{i j c u(a l)}^{*},
$$

where $I_{T}$ is the indicator of the initial data and EML of the transformer; $K_{j}$ is the component of the specific characteristics of used ES corresponding to the indicator $I_{i j c u(a l)}^{*}$ of the EMS with a copper (aluminum) winding.

The main objective functions of structural (in this work) and structural-parametric synthesis characterize the mass $(j=1)$, cost $(j=2)$ and active power losses $(j=3)$ of the EMS of the transformer. The extrema $\left(I^{*}{ }_{i j c u(a l)}\right)^{\prime}$ of the optimization indicators (1) are determined by numerical calculations. The named extrema represent indicators of the technical level of the $i$-th variant of EMS [3].

The values of $I_{i 1(2) c u(a l)}^{*}$ are determined by the filling factor of the winding window with conductive material 
$K_{w}$ (voltage class) and invariant (acceptable for any structures and configurations of EMS elements) relative geometric $\mathrm{CVs}$. The main geometric $\mathrm{CVs}$ are determined by the ratio of the sizes of the diameters of the calculated circles of the magnetic core $D_{1 i}$ and $D_{2 i}$ (Fig. 1-3), as well as by the ratio of the height $h_{w i}$ and the width $b_{w i}$ of the winding window. An additional relative CV used in the part of EMS is the trigonometric function $t\left(\alpha_{c}\right)$ of the central angle of the rod $\alpha_{c}$ (Fig. 1,c, 2,c):

$$
\begin{gathered}
F_{i 1(2) c u(a l)}^{*}=f_{i 1(2) c u(a l)}\left[K_{w}, x_{c}, y_{w}, t\left(\alpha_{c}\right)\right] ; \\
x_{c}=D_{1 j} / D_{2 j} ; \\
y_{w}=h_{w j} / b_{w j} .
\end{gathered}
$$

The optimization indicator $I^{*}{ }^{3} \mathrm{cu}(a l)$, in addition to the CVs (3), (4), depends on the relative electromagnetic CV losses $z_{l}[3,8]$

$$
F_{i 3 c u(a l)}^{*}=f_{i 3 c u(a l)}\left[K_{w}, x_{c}, y_{w}, t\left(\alpha_{c}\right), z_{l}\right] .
$$

The electromagnetic $\mathrm{CV}$ is determined by the ratio of the coefficients of the additional short-circuit $K_{l c u(a l)}$ and the no-load $K_{l c}$ losses, the ratio of the specific losses of the winding (depends on the specific losses $I^{*}{ }_{l c u(a l)}$ and the current density $J_{w c u(a l)}$ of the winding) and the specific losses of ES $l_{s t}$, and also the values of the density of copper (aluminum) $\gamma_{c u(a l)}$ and ES $\gamma_{s t}$

$$
z_{l c u(a l)}=\frac{K_{l c u(a l)} I_{l c u(a l)} J_{w c u(a l)}^{2} \gamma_{c u(a l)}}{K_{l c} \gamma_{s t} l_{s t}} \text {. }
$$

Mathematical models of optimization comparison (structural synthesis) should provide a comparison of EMS options based on the identity of their electromagnetic power $\left(I_{T}\right.$ equality), invariance (universality) of the $\mathrm{CV}$ and independence from the conditions of a specific technical specification of parametric synthesis.

These conditions correspond to the objective functions $F_{i 1(2) c u(a l)}(1)$, the optimization components of which and the optimal geometric EMS ratios according to the particular criteria of the minimums of mass and cost are determined only by the geometric CVs and do not depend on the EML [3]. However, the objective functions $F_{i 3 c u(a l)}$ are additionally determined by the EML. Therefore, in order to exclude the dependence of the generalized structural synthesis on the power, the type of cooling and other design data and limitations, the CV (6) and the value of the $F^{*}{ }_{i 3 c u(a l)}$ indicator should accordingly change and be determined in a certain real design range of the known minimum and maximum calculated EML values.

For an adequate comparison of EMS (Fig. 1-3), in addition to the identity of $I_{T}$, electrical materials, voltage classes, filling factors of the ETS magnetic core $K_{s t}$ and the average values of the magnetic flux density amplitudes of the cross-sections of the magnetic core elements are taken accordingly. The real windings of each EMS are replaced by the calculated windings [3] of structurally and configurationally equivalent reactors.
Due to the lack of experimental data on the specific losses of a three-rod magnetic core and a magnetic core of combined connected plates, for a preliminary comparison of the $I^{*}{ }_{i 3}$ indicators, the design of a radial three-rod EMS with three anisotropic parallelogram ES plates in each layer of the magnetic core is adopted. In this case, it is possible to estimate the dependence of losses on the structural features of the EMS (Fig. 1-3) in the same range of variation of the electromagneticCV (6). The real design range of change of $z_{l c u(a l)}$ of transformers calculated using ES 3407 is taken. It is found that such a range of change of the electromagnetic relative $\mathrm{CV}$ is identical for copper and aluminum windings [8]

$$
3 \leq z_{l c u(a l)} \leq 24 .
$$

Indicators (2), (5) of the objective functions (1) of the rod EMS (Fig. 1) are represented by the equations:

$$
\begin{gathered}
I_{11 c u(a l)}^{*}=\left(\sqrt[4]{\frac{\sin \alpha_{c} K_{s t} K_{w} y_{w}\left(x_{c}-\sin \frac{\alpha_{c}}{2}\right)^{2}}{8}}\right)^{3}\left\{0,5 K_{s t} \times\right. \\
\times \sin \alpha_{c}\left[\left(x_{c}-\sin \frac{\alpha_{c}}{2}\right) 0,5 y_{w}+\left(x_{c}-\sin \frac{\alpha_{c}}{2}\right)+\sin \alpha_{c}\right]+ \\
+K_{w} y_{w}\left\{0,25\left(x_{c}-\sin \frac{\alpha_{c}}{2}\right)^{2}\left[\cos \alpha_{c}+\sin \alpha_{c}+\right.\right. \\
\left.\left.\left.+\frac{\pi}{4}\left(x_{c}-\sin \frac{\alpha_{c}}{2}\right)\right]\right\} \gamma_{w c u(a l)} / \gamma_{s t}\right\}
\end{gathered}
$$

$I_{12 c u(a l)}^{*}=\left(\sqrt[4]{\frac{8}{\sin \alpha_{c} K_{s t} K_{w} y_{w}\left(x_{c}-\sin \frac{\alpha_{c}}{2}\right)^{2}}}\right)^{3}\left\{0,5 K_{s t} \times\right.$ $\times \sin \alpha_{c}\left[\left(x_{c}-\sin \frac{\alpha_{c}}{2}\right) 0,5 y_{w}+\left(x_{c}-\sin \frac{\alpha_{c}}{2}\right)+\sin \alpha_{c}\right]+$$$
+K_{w} y_{w}\left\{0,25\left(x_{c}-\sin \frac{\alpha_{c}}{2}\right)^{2}\left[\cos \alpha_{c}+\sin \alpha_{c}+\right.\right.
$$$$
\left.\left.\left.+\frac{\pi}{4}\left(x_{c}-\sin \frac{\alpha_{c}}{2}\right)\right]\right\} C_{w c u(a l)} \gamma_{w c u(a l)} /\left(C_{s t} \gamma_{s t}\right)\right\} ;
$$

$$
I_{13 c u(a l)}^{*}=K_{l c}\left(\sqrt[4]{\frac{8}{\sin \alpha_{c} K_{s t} K_{w} y_{w}\left(x_{c}-\sin \frac{\alpha_{c}}{2}\right)^{2}}}\right)^{3} \times
$$$$
\times\left\{0,5 K_{s t} \sin \alpha_{c}\left[\left(x_{c}-\sin \frac{\alpha_{c}}{2}\right) 0,5 y_{w}+\left(x_{c}-\sin \frac{\alpha_{c}}{2}\right)+\right.\right.
$$

$\left.+\sin \alpha_{c}\right]+K_{w} y_{w}\left\{0,25\left(x_{c}-\sin \frac{\alpha_{c}}{2}\right)^{2}\left[\cos \alpha_{c}+\sin \alpha_{c}+\right.\right.$ 


$$
\left.\left.\left.+\frac{\pi}{4}\left(x_{c}-\sin \frac{\alpha_{c}}{2}\right)\right]\right\} z_{l c u(a l)} \gamma_{w c u(a l)} / \gamma_{s t}\right\} .
$$

Indicators (2), (5) of the objective functions (1) of the armor EMS (Fig. 2) are determined by the equations:

$$
\begin{aligned}
& I_{21 c u(a l)}^{*}=\left(\sqrt[4]{\frac{8}{\sin \alpha_{c} K_{s t} K_{w} y_{w}\left(x_{c}-\sin \frac{\alpha_{c}}{2}\right)^{2}}}\right)^{3} \times \\
& \times\left\{0,5 K_{s t} \sin \alpha_{c}\left[\left(x_{c}-\sin \frac{\alpha_{c}}{2}\right) 0,5 y_{w}+\left(x_{c}-\sin \frac{\alpha_{c}}{2}\right)+\right.\right. \\
& \left.+\sin \frac{\alpha_{c}}{2}\right]+K_{w} y_{w}\left\{0,25\left(x_{c}-\sin \frac{\alpha_{c}}{2}\right)^{2}\left[2 \cos \frac{\alpha_{c}}{2}+\right.\right. \\
& \left.\left.\left.+2 \sin \frac{\alpha_{c}}{2}+\frac{\pi}{2}\left(x_{c}-\sin \frac{\alpha_{c}}{2}\right)\right]\right\} \gamma_{w c u(a l)} / \gamma_{s t}\right\} \\
& I_{22 c u(a l)}^{*}=\left(\sqrt[4]{\frac{1}{0,5 \sin \alpha_{c} K_{s t} K_{w} y_{w}\left(x_{c}-\sin \frac{\alpha_{c}}{2}\right)^{2}}}\right)^{3} \times \\
& \times\left\{0,5 K_{s t} \sin \alpha_{c}\left[\left(x_{c}-\sin \frac{\alpha_{c}}{2}\right) 0,5 y_{w}+\left(x_{c}-\sin \frac{\alpha_{c}}{2}\right)+\right.\right. \\
& \left.+\sin \frac{\alpha_{c}}{2}\right]+K_{w} y_{w}\left\{0,25\left(x_{c}-\sin \frac{\alpha_{c}}{2}\right)^{2}\left[\cos \alpha_{c}+\sin \alpha_{c}+\right.\right. \\
& \left.+\frac{\pi}{2}\left(x_{c}-\sin \frac{\alpha_{c}}{2}\right) C_{w c u(a l)} \gamma_{w c u(a l)} /\left(C_{s t} \gamma_{s t}\right)\right\} ; \\
& I_{23 c u(a l)}^{*}=K_{l c}\left(\sqrt[4]{\frac{1}{0,5 \sin \alpha_{c} K_{s t} K_{w} y_{w}\left(x_{c}-\sin \frac{\alpha_{c}}{2}\right)^{2}}}\right)^{3} \times \\
& \times\left\{0,5 K_{s t} \sin \alpha_{c}\left[\left(x_{c}-\sin \frac{\alpha_{c}}{2}\right) 0,5 y_{w}+\left(x_{c}-\sin \frac{\alpha_{c}}{2}\right)+\right.\right.
\end{aligned}
$$

Extreme values of indicators of the mass of options for single-phase electromagnetic systems of transformers with copper and aluminum windings

\begin{tabular}{|c|c|c|c|}
\hline \multirow{2}{*}{$\begin{array}{c}\text { Designation of mass indicator } \\
\text { extremum }\end{array}$} & \multicolumn{3}{|c|}{$\begin{array}{c}\text { Value of mass indicator extremum, at values of } \\
\text { winding window fill factor }\end{array}$} \\
\cline { 2 - 4 } & 0,3 & 0,25 & 22,633 \\
\hline$\left(I^{*}{ }_{11}^{\prime}\right)_{c u}^{\prime}$ & 20,201 & 21,234 & 13,641 \\
\hline$\left(I_{11}^{\prime}\right)_{a l}^{\prime}$ & 11,841 & 12,605 & 23,600 \\
\hline$\left(I^{*}{ }^{\prime}\right)_{c u}^{\prime}$ & 20,714 & 21,941 & 14,887 \\
\hline$\left(I^{*}{ }_{21}^{\prime}\right)_{a l}^{\prime}$ & 12,747 & 13,656 & 19,859 \\
\hline$\left(I^{*}\right)_{c u}^{\prime}$ & 17,574 & 18,544 & 12,251 \\
\hline$\left(I^{*}{ }_{11}^{\prime}\right)_{a l}^{\prime}$ & 10,556 & 11,275 & \\
\hline
\end{tabular}

$\left.+\sin \frac{\alpha_{c}}{2}\right]+K_{w} y_{w}\left\{0,25\left(x_{c}-\sin \frac{\alpha_{c}}{2}\right)^{2}\left[\cos \alpha_{c}+\sin \alpha_{c}+\right.\right.$

$$
\left.+\frac{\pi}{2}\left(x_{c}-\sin \frac{\alpha_{c}}{2}\right) z_{l c u(a l)} \gamma_{w c u(a l)} / \gamma_{s t}\right\}
$$

The equations of indicators (2), (5) of the objective functions (1) of the radial three-rod EMS (Fig. 3) are as follows:

$$
\begin{aligned}
& I_{31 c u(a l)}^{*}=2,394\left(\sqrt[4]{\frac{1}{K_{s t} K_{w} y_{w}\left(x_{c}-1\right)}}\right)^{3}\left\{K_{w} y_{w}\left(x_{c}-1\right) \times\right. \\
& \times\left(x_{c}+0,5\right)+0,75 K_{w} \times \\
& \left.\times\left(y_{w}+2 x_{c}-0,9532\right) \gamma_{w c u(a l)} / \gamma_{s t}\right) \text {; } \\
& I_{32 c u(a l)}^{*}=2,394\left(\sqrt[4]{\frac{1}{K_{s t} K_{w} y_{w}\left(x_{c}-1\right)}}\right)^{3}\left\{K_{w} y_{w}\left(x_{c}-1\right) \times\right. \\
& \times\left(x_{c}+0,5\right)+0,75 K_{w}\left(y_{w}+2 x_{c}-0,9532\right) \times \\
& \left.\times C_{w c u(a l)} \gamma_{w c u(a l)} / C_{s t} \gamma_{s t}\right\} \text {; } \\
& I_{33 c u(a l)}^{*}=2,394 K_{l c}\left(\sqrt[4]{\frac{1}{K_{s t} K_{w} y_{w}\left(x_{c}-1\right)}}\right)^{3} \times \\
& \times\left\{K_{s t} y_{w}\left(x_{c}-1\right)\left(x_{c}+0,5\right)+0,75 K_{w} \times\right. \\
& \left.\times z_{l c u(a l)}\left(y_{w}+2 x_{c}-0,9532\right)\right\} .
\end{aligned}
$$

Calculations according to equations (7) - (15) are performed at $K_{s t}=0.97$ and values $K_{w}=0.3 ; 0.25 ; 0.15$, as well as in real ranges of cost ratios $C_{w c u(a l)}$ and $C_{s t}$ of copper (aluminum) winding conductors, taking into account insulation and ES:

$\left(C_{w c u} / C_{s t}\right)=3,5-5,5 ;\left(C_{w a l} / C_{s t}\right)=3-4,7$.

The results of calculations of indicators of the technical level of EMS (Fig. 1-3) are shown in Table 1-4.

From the calculation results of Table 1-4 the potential for improvement of single-phase transformers with laminated magnetic cores based on a spatial radial electromagnetic system with a three-rod magnetic circuit follows.

Table 1 
Extreme values of indicators of the cost of options for single-phase electromagnetic systems of transformers with copper windings

\begin{tabular}{|c|c|c|c|c|}
\hline \multirow{2}{*}{$\begin{array}{c}\text { Designation of cost } \\
\text { indicator extremum }\end{array}$} & \multirow{2}{*}{$\begin{array}{c}\text { Winding window fill } \\
\text { factor }\end{array}$} & \multicolumn{3}{|c|}{$\begin{array}{c}\text { Value of cost indicator extremum, at values of } \\
\text { ratio of material costs }\end{array}$} \\
\cline { 2 - 5 } & & 3,5 & 4,5 & 5,5 \\
\hline \multirow{3}{*}{$\left(I^{*}{ }_{12}^{\prime}\right)_{c u}^{\prime}$} & 0,3 & 38,789 & 44,721 & 50,229 \\
\cline { 2 - 5 } & 0,25 & 40,205 & 46,228 & 51,815 \\
\cline { 2 - 5 } & 0,2 & 42,122 & 48,271 & 53,963 \\
\hline \multirow{3}{*}{$\left(I^{*}{ }_{22}\right)_{c u}^{\prime}$} & 0,3 & 37,694 & 43,003 & 47,906 \\
\cline { 2 - 5 } & 0,25 & 39,374 & 44,215 & 52,337 \\
\cline { 2 - 5 }$\left(I^{*}{ }_{32}\right)_{c u}^{\prime}$ & 0,2 & 41,648 & 47,215 & 52,337 \\
\cline { 2 - 5 } & 0,3 & 32,855 & 37,687 & 45,164 \\
\cline { 2 - 5 } & 0,25 & 34,183 & 39,101 & 43,651 \\
\hline
\end{tabular}

Extreme values of indicators of the cost of options for single-phase electromagnetic systems of transformers with aluminum windings

\begin{tabular}{|c|c|c|c|c|}
\hline \multirow{2}{*}{$\begin{array}{c}\text { Designation of cost } \\
\text { indicator extremum }\end{array}$} & \multirow{2}{*}{$\begin{array}{c}\text { Winding window fill } \\
\text { factor }\end{array}$} & \multicolumn{3}{|c|}{$\begin{array}{c}\text { Value of cost indicator extremum, at values of } \\
\text { ratio of material costs }\end{array}$} \\
\cline { 2 - 5 } & 0,3 & 3 & 3,8 & 4,7 \\
\hline \multirow{3}{*}{$\left(I^{*}{ }_{12}\right)_{a l}^{\prime}$} & 0,25 & 19,268 & 21,601 & 24,009 \\
\cline { 2 - 5 } & 0,2 & 20,276 & 22,671 & 25,137 \\
\cline { 2 - 5 } & 0,3 & 21,641 & 24,118 & 26,664 \\
\hline \multirow{3}{*}{$\left(I^{*}{ }_{22}\right)_{a l}^{\prime}$} & 0,25 & 19,878 & 22,064 & 24,303 \\
\cline { 2 - 5 } & 0,2 & 21,075 & 23,335 & 27,643 \\
\hline \multirow{3}{*}{$\left(I^{*}{ }_{32}\right)_{a l}^{\prime}$} & 0,3 & 22,697 & 25,055 & 20,729 \\
\cline { 2 - 5 } & 0,25 & 16,798 & 18,736 & 21,788 \\
\cline { 2 - 5 } & 0,2 & 17,745 & 19,741 & 23,224 \\
\hline
\end{tabular}

Extreme values of indicators of the loss of options for single-phase electromagnetic systems of transformers with copper and aluminum windings

\begin{tabular}{|c|c|c|c|c|}
\hline \multirow{2}{*}{$\begin{array}{l}\text { Designation of loss } \\
\text { indicator extremum }\end{array}$} & \multirow{2}{*}{$\begin{array}{l}\text { Winding window fill } \\
\text { factor }\end{array}$} & \multicolumn{3}{|c|}{$\begin{array}{l}\text { Value of loss indicator extremum, at values of } \\
\text { electromagnetic controlled variable }\end{array}$} \\
\hline & & 3 & 8 & 24 \\
\hline \multirow{3}{*}{$\left(I_{13}^{*}\right)_{\mathrm{cu}}^{\prime}$} & 0,3 & 35,613 & 62,764 & 125,456 \\
\hline & 0,25 & 36,975 & 64,508 & 127,754 \\
\hline & 0,2 & 38,819 & 66,868 & 130,873 \\
\hline \multirow{3}{*}{$\left(I^{*}{ }^{*}\right)_{a l}^{\prime}$} & 0,3 & 19,268 & 31,663 & 59,145 \\
\hline & 0,25 & 21,276 & 32,952 & 60,846 \\
\hline & 0,2 & 21,64 & 34,699 & 63,148 \\
\hline \multirow{3}{*}{$\left(I_{23}^{*}\right)_{c u}^{\prime}$} & 0,3 & 34,914 & 59,137 & 113,562 \\
\hline & 0,25 & 36,531 & 61,207 & 116,289 \\
\hline & 0,2 & 38,722 & 64,011 & 120,308 \\
\hline \multirow{3}{*}{$\left(I_{23}^{*}\right)_{a l}^{\prime}$} & 0,3 & 19,451 & 31,329 & 55,938 \\
\hline & 0,25 & 21,075 & 32,861 & 57,957 \\
\hline & 0,2 & 22,697 & 34,935 & 60,692 \\
\hline \multirow{3}{*}{$\left(I^{*}{ }_{33}\right)_{c u}^{\prime}$} & 0,3 & 30,261 & 52,321 & 102,786 \\
\hline & 0,25 & 31,539 & 53,953 & 104,935 \\
\hline & 0,2 & 33,269 & 56,165 & 107,846 \\
\hline \multirow{3}{*}{$\left(I^{*}{ }_{33}\right)_{a l}^{\prime}$} & 0,3 & 16,798 & 27,027 & 49,392 \\
\hline & 0,25 & 17,745 & 28,237 & 50,985 \\
\hline & 0,2 & 19,028 & 29,877 & 53,143 \\
\hline
\end{tabular}




\section{Conclusions.}

1. It is found that the decrease in the extrema of the mass and cost indicators, as well as the calculated decrease, with the conditional identity of the additional loss coefficients, the extrema of active power loss of a single-phase radial three-rod EMS of the transformer relative to a planar analogue with a rod laminated magnetic circuit made of anisotropic ES is, respectively, $13-12.3 \%, 15.3-10.1 \%$ and 15.1-18.1 \% with copper windings and 10.8-10.2\%, 12.8-13.7\% and 12.6-12.3\% with aluminum windings.

2. Decrease in the number and volume of ES of the angular zones of the magnetic core of the radial three-rod EMS relative to traditional planar analogs creates the prerequisites for additional energy saving by reducing the main and additional losses of the magnetic cores; it also seems expedient to combine anisotropic and isotropic ES in the rod and yoke-angular sections.

3. The main technical level indicators of traditional single-phase planar EMS with rod and armored magnetic cores differ insignificantly, which agrees with the previously known optimization and design data of transformers.

\section{REFERENCES}

1. Lizunov S.D., Lokhanin A.K. Power Transformers. A Reference Book. Moscow, Energoatomizdat Publ., 2004. 616 p. (Rus).

2. Stavinskiy A.A. Evolution of structures and preconditions for transformers and reactors improvement via electromagnetic system circuit transformation (systems with laminated and twisted magnetic circuits). Electrical engineering \& electromechanics, 2011, no. 6, pp. 33-38. (Rus).

3. Stavinskiy A.A., Stavinskiy R.A., Avdeeva E.A. Optimization comparative analysis of the structures of static electromagnetic systems. Part 1. Variants and a method for evaluating transformations. Electricity, 2014, no. 9, pp. 34-43. (Rus).

4. Kefalas T.D., Kladas A.G. Reduction of cost and losses of transformers by using composite magnetic cores. 2014 International Conference on Electrical Machines (ICEM), Sep. 2014. doi: 10.1109/icelmach.2014.6960499.
5. Levin M.I., Pentegov I.V., Rymar S.V., Lavreniuk A.V. New approaches at construction of magnetic conductors for mains transformers. Electrical engineering \& electromechanics, 2015, no. 1, pp. 20-24. doi: 10.20998/2074-272x.2015.1.04. (Rus).

6. Magdaleno-Adame S., Melgoza-Vazquez E., OlivaresGalvan J.C., Escarela-Perez R. Loss reduction by combining electrical steels in the core of power transformers. International Transactions on Electrical Energy Systems, 2016, vol. 26, no. 8, pp. 1737-1751. doi: 10.1002/etep.2175.

7. Kostinskiy S.S. The review of the condition of branch of transformer manufacture and tendencies of development of the design of power transformers. Izvestiya vysshikh uchebnykh zavedenii. Problemy energetiki, 2018, vol. 20, no. 1-2, pp. 1432. (Rus). doi: 10.30724/1998-9903-2018-20-1-2-14-32.

8. Stavinskiy A.A., Avdeeva O.A., Tsiganov O.M., Stavinskiy R.A., Sadoviy O.S. Comparison of three-phase transformers with rectangular and circular conversion of laminated magnetic cores (active power losses). Bulletin of NTU «KhPI». Series: «Electric machines and electromechanical energy conversion», 2019, no. 4 (1329), pp. 38-43. (Ukr). doi: 10.20998/24099295.2019.4.06.

9. Khatri A., Rahi O.P. Optimal design of transformer: A Compressive bibliographical survey. International Journal of Scientific Engineering and Technology, 2012, vol. 1, no. 2, pp. 159-167.

10. Amadi-Echendu J.E., Mafutsana J.M. A bibliographic review of trends in design and management of electrical power transformers. Proceedings of the 2016 International Conference on Industrial Engineering and Operations Management. Cuala Lumpur, Malaysia. 10 March, 2016, pp. 2010-2018.

Received 06.09.2020

Accepted 09.10.2020

Published 24.12.2020

\author{
A.A. Stavinskiy ${ }^{1}$, Doctor of Technical Science, Professor, \\ A.M. Tsyganov ${ }^{1}$, Assistant, \\ ${ }^{1}$ Mykolayiv National Agrarian University, \\ 9, George Gongadze Str., Mykolaiv, 54020, Ukraine, \\ e-mail: andrey.stavynskiy@mnau.edu.ua, \\ potomkinske@gmail.com
}

How to cite this article:

Stavinskiy A.A., Tsyganov A.M. Design and technological proposals for improving a single-phase transformer with laminated magnetic core. Electrical engineering \& electromechanics, 2020, no. 6, pp. 11-17. doi: 10.20998/2074272X.2020.6.02. 